\title{
Short-term immunosuppressive therapy does not affect the density of the pre-existing bone around titanium implants placed in rabbits
}

\section{Terapia imunossupressora não afeta a densidade do osso preexistente ao redor de implantes de titânio inseridos em coelhos}

Poliana Mendes Duarte*

Getúlio Rocha Nogueira Filho**

Enilson Antônio Sallum**

Antonio Wilson Sallum***

Francisco Humberto Nociti Júnior**

\begin{abstract}
The aim of this study was to evaluate the influence of the administration and withdrawal of cyclosporin A/nifedipine on the bone density in a lateral area adjacent to implants placed in rabbits. Two screw-type titanium implants were placed bilaterally in twenty-eight New Zealand rabbits. The animals were assigned to one of the following groups and received daily subcutaneous injections for 14 days: Groups A and C: vehicle (dimethyl sulfoxide); Groups B and D: CsA (10 mg/kg) plus nifedipine $(50 \mathrm{mg} / \mathrm{kg})$. The animals in Groups A and B were sacrificed 14 days postoperatively and, in Groups C and D, 42 days postoperatively. After sacrifice, the tibiae were removed and undecalcified sections were obtained. Bone density was obtained in a $500 \mu \mathrm{m}$-wide zone lateral to the implant surface. Intergroup analysis showed no significant difference $(p>0.05)$ in the degree of bone density between control and test groups either on day 14 or on day 42 . Thus, it appears that a short-term immunosuppressive therapy may not present a negative influence on the density of the pre-existing bone around titanium implants placed in rabbits.
\end{abstract}

DESCRIPTORS: Titanium; Osseointegration; Cyclosporine; Nifedipine; Dental implants.

\begin{abstract}
RESUMO: O objetivo deste trabalho foi avaliar a influência da administração de ciclosporina A (CsA)/nifedipina e sua interrupção na densidade óssea em uma região lateral à superficie de implantes de titânio inseridos em coelhos. Dois implantes de titânio comercialmente puros foram inseridos bilateralmente em vinte e oito coelhos. Os animais foram aleatoriamente divididos em um dos seguintes grupos experimentais, recebendo injeções diárias subcutâneas por 14 dias: Grupos A e C: veículo (dimetil sulfóxido); Grupos B e D: CsA (10 mg/ kg) e nifedipina (50 mg/kg). Os animais pertencentes aos Grupos A/B e C/D foram sacrificados 14 e 42 dias após a colocação dos implantes, respectivamente. Após o sacrificio, as tíbias foram removidas para a obtenção de secções não-descalcificadas. A densidade óssea foi obtida em uma zona de $500 \mu \mathrm{m}$ lateral à superficie do implante através de análise histométrica. A análise intergrupo não revelou diferenças para os grupos teste e controle em 14 e 42 dias ( $>$ > 0,05). Dentro dos limites deste estudo podemos concluir que a associação CsA/nifedipina, administrada em um curto prazo, não apresenta uma influência negativa na densidade do osso preexistente ao redor de implantes de titânio inseridos em coelhos.

DESCRITORES: Titânio; Osseointegração; Ciclosporina; Nifedipina; Implantes dentários.
\end{abstract}

\section{INTRODUCTION}

The use of titanium endosseous dental implants has been described for the treatment of edentulous or partially edentulous patients in order to restore function and esthetics ${ }^{3,24}$. However, the success of osseointegration depends on the state of the host bone and its healing capacity. Thus, some local and systemic conditions may im- pair bone healing or may interfere with the maintenance of osseointegration ${ }^{10}$.

Organ transplantation has increased in the last decade following successful development of immunosuppressive drug regimens to reduce rejection reports. Cyclosporin $\mathrm{A}(\mathrm{Cs} \mathrm{A})$ is the most commonly used immunosuppressant agent for preventing graft rejection. It is a fungal cyclic undecapeptide, which has also shown promise in

*PhD Student; **Assistant Professors; ${ }^{* * *}$ Chairman, Professor - Department of Prosthodontics and Periodontics, Division of Periodontics, School of Dentistry of Piracicaba, State University of Campinas. 
Duarte PM, Nogueira Filho GR, Sallum EA, Sallum AW, Nociti Júnior FH. Short-term immunosuppressive therapy does not affect the density of the pre-existing bone around titanium implants placed in rabbits. Pesqui Odontol Bras 2003;17(4):362-6.

the treatment of autoimmune disorders such as psoriasis, atopic dermatitis, rheumatoid arthritis and uveits ${ }^{17}$. Its major effect on the immune system is inhibition of T-cell action and proliferation, thereby altering the T-cell-mediated immune response. It has also been shown to affect a subset of $\mathrm{B}$ cells $^{22}$.

In addition to its effects on the immune system, CsA has also been associated with deleterious effects upon bone metabolism ${ }^{16}$. Nevertheless, despite its many therapeutic uses and its efficient prevention of organ rejection ${ }^{25}$, side-effects are not infrequent. Post-transplantation osteoporosis ${ }^{4,15}$, bone formation and bone resorption are well-recognized side-effects ${ }^{5,6,14,19,27}$. Moreover, CsA administration has been associated with gingival overgrowth and nephrotoxicity ${ }^{17}$.

In order to control hypertension and reduce cyclosporin-induced nephrotoxicity ${ }^{11}$, patients are frequently given nifedipine, a calcium-channel blocker (CCBs). The effect of CCBs appears not to be limited only to the cardiovascular system, but also to calcium metabolism. Similarly to CsA, nifedipine has demonstrated some effects on bone metabolism $^{9,29}$.

Therefore, the present study was designed to evaluate, by histological analysis, whether shortterm $\mathrm{CsA} /$ nifedipine administration influences bone density, in a pre-existing bone area, around titanium implants placed in the tibiae of rabbits. In addition, the study also aims to investigate whether recovery is possible following administration withdrawal.

\section{MATERIAL AND METHODS Animals}

Twenty-eight male New Zealand rabbits 13,000 to $3,500 \mathrm{~g}$ ), aged 9 to 12 months, were used in the entire study. The animals were kept in individual cages with access to food and water ad libitum. Prior to the surgical procedures, all animals were allowed to acclimatize to the laboratory environment for a period of 7 days. The protocol was approved by the University of Campinas Institutional Animal Care and Use Committee.

\section{Implant surgery}

At the beginning of the experiment, general anesthesia was performed using intramuscular administration of ketamine $(0.5 \mathrm{ml} / \mathrm{kg})$. The tibiae skin was shaved and disinfected with iodine surgical soap. A $30 \mathrm{~mm}$ incision was made and the bone surface of the tibiae surgically exposed by blunt dissection. Under profuse saline solution irrigation, unicortical implant beds were drilled and two screw-shaped commercially available pure titanium implants $(7.0 \mathrm{~mm}$ in length and $3.75 \mathrm{~mm}$ in diameter) were placed bilaterally until the screw thread had been completely introduced into the bone cortex. Finally, soft tissues were replaced and sutured. Postoperatively, the animals received antibiotic (Pentabiótico ${ }^{\circledR}$, Wyeth-Whitehall Ltda., São Paulo, SP, Brazil) given as a single intramuscular injection.

\section{Experimental design}

Immediately after implant placement, the animals were randomly assigned to one of the following four treatment groups (7 animals/group) and received daily subcutaneous injections for 14 days: Groups A and $C$ were injected with a vehicle (dimethyl sulfoxide) and groups $B$ and $D$ received CsA (Sandimmun ${ }^{\circledR}$, Novartis Pharma AG, Switzerland) $(10 \mathrm{mg} / \mathrm{kg})$ plus nifedipine (Sigma, St. Louis, MO, USA) (50 mg/kg). Groups A and B were sacrificed 14 days postoperatively and Groups C and D were sacrificed 42 days postoperatively (Figure 1).

\section{Histometric procedures}

After sacrifice, the tibiae were removed and fixed in $4 \%$ neutral formalin for 48 hours. Undecalcified sections were prepared as previously described $^{7}$, i.e. the blocks were dehydrated by using an ascending series of ethanol (60-100\%) and embedded in glycolmethacrylate (Technovit $7200^{\oplus}$; Heraeus Kulzer GmbH, Wehrheim, Germany). Subsequently, sections (20-30 $\mu \mathrm{m})$ were obtained and stained as follows: (1) the slide-containing specimen was placed in a vessel containing Stevenel's blue preheated to $60^{\circ} \mathrm{C}$, and maintained at this temperature for 15 minutes; (2) the speci-

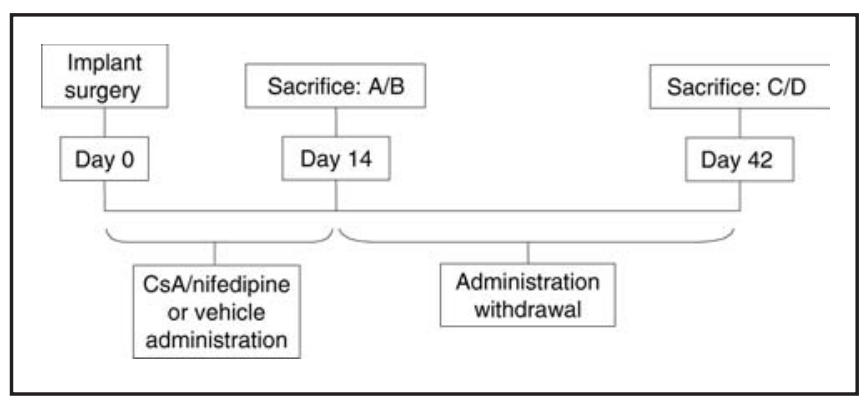

FIGURE 1 - Diagram illustrating the experimental design. 
Duarte PM, Nogueira Filho GR, Sallum EA, Sallum AW, Nociti Júnior FH. Short-term immunosuppressive therapy does not affect the density of the pre-existing bone around titanium implants placed in rabbits. Pesqui Odontol Bras 2003;17(4):362-6.

men was rinsed in distilled water at $60^{\circ} \mathrm{C}$ and air dried; (3) a small amount of alizarin red stain was placed onto the specimen surface at room temperature for 5 minutes. The specimen was then washed thoroughly in running distilled water to remove excess stain and air-dried. Bone density (BD), i.e., the proportion of mineralized matrix, in a $500 \mu \mathrm{m}$-wide zone lateral to the implant surface, was separately recorded for both sides of the implant (Image-Pro ${ }^{\circledR}$; Media Cybernetics, Silver Spring, MD, USA).

\section{Statistical analysis}

The hypothesis that the CsA/nifedipine association had no influence on the bone density was tested by an intergroup analysis (Group A versus Group B and Group C versus Group D) using Mann-Whitney's test $(\alpha=0.05)$. In addition, to test the hypothesis that this immunossupressant therapy does not influence body weight during the experimental period, the Student's $t$ test was used $(\alpha=0.05)$.

\section{RESULTS \\ Clinical observations}

On day 14, all animals showed some weight loss. However, the animals that received immunosuppressive therapy demonstrated a significantly greater weight loss $(-0.41 \pm 0.20 \mathrm{~kg})$ than the control group $(-0.16 \pm 0.10 \mathrm{~kg})(\mathrm{p}=0.01)$. On day 42, after withdrawal of the immunosuppressive therapy, the control group presented a weight gain $(0.27 \pm 0.18 \mathrm{~kg})$ and the test group still presented some weight loss $(-0.04 \pm 0.37 \mathrm{~kg})$; how-

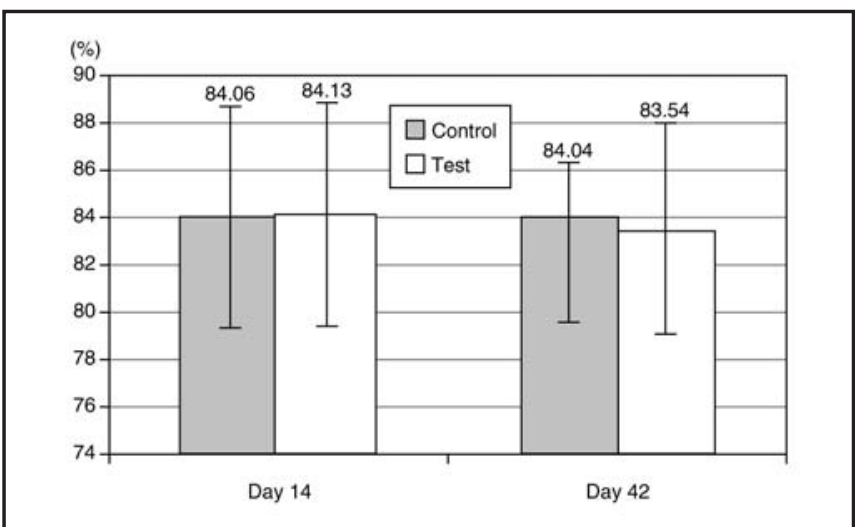

GRAPH 1 - Mean and standard deviation of bone density in a $500 \mu \mathrm{m}$-wide zone lateral to the implant surface between test and control groups on days 14 and 42 . ever, there was no statistical difference between the groups $(p=0.07)$. Due to the sample variability, these data should be considered with caution.

\section{Histometric results}

Intergroup analysis did not show statistical difference $(p>0.05)$ between test and control groups regarding bone density either on day 14 , during the $\mathrm{CsA} /$ nifedipine administration, or on day 42 , after the withdrawal of immunosuppressive therapy. Graph 1 illustrates the results observed for all the experimental groups. Figure 2 illustrates the histological aspects observed in the test group on days 14 and 42 .

\section{DISCUSSION}

High success rates have been reported for implant-supported prostheses in fully and partially edentulous patients ${ }^{3,24}$. However, among other factors, the medical status of the patients has been associated with biological failures of dental implants ${ }^{10}$. Immunosuppression is a therapeutic regimen for several diseases ${ }^{17}$, including lifelong medication with drug associations such as $\mathrm{CsA} /$ nifedipine in order to counteract rejection of transplanted tissues. Recently, the significance of CsA on alveolar bone has received some attention $^{14}$. Thus, with the growth in implant demand, use of immunosuppressive therapy before or during implantation should be considered.

Since the prognosis of an implant-supported prosthesis may be influenced by the bone density
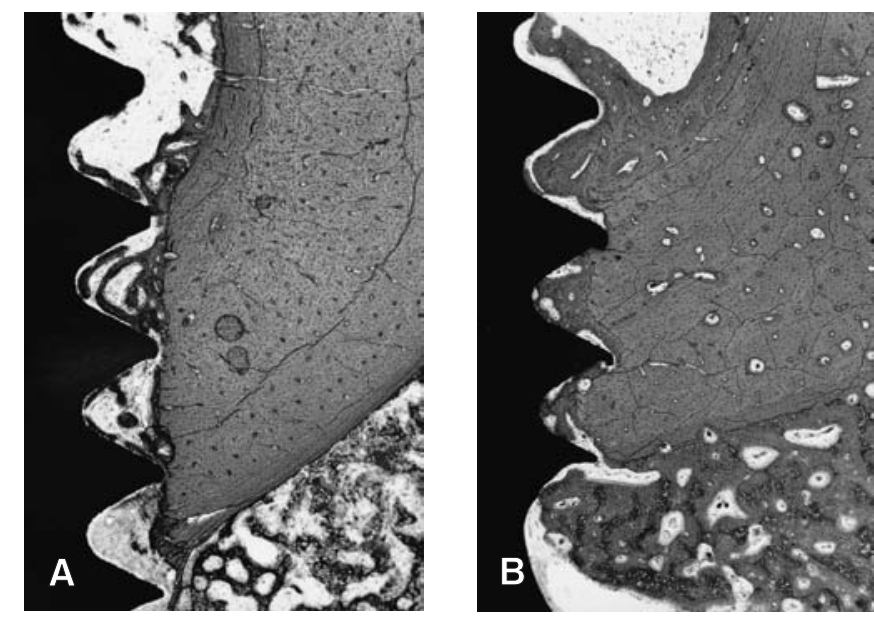

FIGURE 2 - Photomicrographs illustrating the histological aspects observed in a $500 \mu \mathrm{m}$-wide zone lateral to the implant surface. Figures $\mathbf{A}$ and $\mathbf{B}$ illustrate test groups at 14 and 42 days, respectively. (Stevenel's blue and alizarin red stain; $15.75 \mathrm{X}$ ). 
Duarte PM, Nogueira Filho GR, Sallum EA, Sallum AW, Nociti Júnior FH. Short-term immunosuppressive therapy does not affect the density of the pre-existing bone around titanium implants placed in rabbits. Pesqui Odontol Bras 2003;17(4):362-6.

around the implant, the present study aimed to evaluate the influence of an immunosuppressive therapy and its withdrawal on the proportion of mineralized bone (bone density) on a $500 \mu \mathrm{m}$-wide zone lateral to the implant inserted in rabbits. The results of the present study demonstrated that short-term administration of CsA/nifedipine may not affect the pre-existing bone adjacent to the implant surface.

Increased bone remodeling and trabecular bone loss have been observed in CsA-exposed animals $^{8,13,21}$. Increased osteoblastic and decreased osteoclastic activity in patients undergoing CsA treatment have also been reported ${ }^{23}$. The precise mechanisms underlying the CsA effect on bone metabolism are still unknown. However, it may be suggested that CsA affects the immune system by selectively influencing the lymphokine-monokine cascade and it has been recognized that cytokines, such as interleukin-1, are among a number of products of the lymphokine-monokine cascade that affect bone metabolism ${ }^{20}$. Although in vitro studies indicate that $\mathrm{CsA}$ inhibits bone resorption $^{27}$, it has been observed that, in vivo, CsA administration results in a severe high turnover osteopenic state ${ }^{2,4}$, which is dependent on both the dose and duration of the therapy ${ }^{26}$.

The subcutaneous route, used in this study, has been suggested as the route of choice to provide a more consistent cycle of CsA availability than any other route. Blood levels of CsA between 100 and $400 \mathrm{ng} / \mathrm{ml}$ have been shown to be sufficient to promote immunosuppression in humans $^{30}$. Likewise, in animals, blood levels between 100 and $400 \mathrm{ng} / \mathrm{ml}$ have been considered to be effective $^{1}$. The dosage of CsA used in the present study (10 mg/kg, S.Q.) has been shown to produce blood levels sufficient to induce immunosuppression in rodents ${ }^{12}$.

The most sensitive index of systemic CsA side-effects appears to be a decrease in renal func- tion. Calcium-channel blockers (CCB), such as nifedipine, have been successfully utilized for the control of CsA-induced toxicity as well as hypertension $^{11}$. A number of clinical and experimental studies have suggested that the effects of CCBs are not only limited to the cardiovascular system but might also involve skeletal calcium metabolism, due to the presence of calcium channels in bone cells $^{9,28,29}$. Though the mechanisms of the effects of CCBs on bone remain obscure, some explanations may be proposed. Calcium antagonists inhibit calcium intracellular influx and there is no doubt that calcium plays an essential role in the mechanism for controlling bone resorption ${ }^{29}$. Osteoclast activity depends upon calcium concentration, and $\mathrm{CCBs}$ can lead to a rapid increase of cytosolic free calcium with effects on osteoclast morphology and a marked dose-dependent fall in the cell spread area and osteoclast bone resorption ${ }^{29}$. Clinically, it has been reported that, in elderly patients treated for coronary heart disease over 2 years, nifedipine caused a temporary increase in bone mineral density $^{18}$.

\section{CONCLUSION}

In conclusion, the results of the present study suggest that short-term administration of CsA, associated with nifedipine, may not influence bone density in a lateral zone to the titanium implant surface inserted in rabbits. However, further studies should be considered in order to address the long-term consequences of maintenance dosage schedules of CsA/nifedipine on bone mineral metabolism around titanium implants.

\section{ACKNOWLEDGMENT}

The authors greatly appreciated the assistance of AS Technology, for supplying the implants.

\section{REFERENCES}

1. Borel JF. Pharmacology of cyclosporine (Sandimmune) IV. Pharmacological properties in vivo. Pharmacol Rev 1989; 421:259-371.

2. Bourbigot B, Moal MC, Cledes J. Bone histology in renal transplant patients receiving cyclosporin. Lancet 1988; $1: 1048$.

3. Branemark PI. Osseointegration and its experimental background. J Prosthet Dent 1983;50:390-410.
4. Cueto-Manzano AM, Konel S, Hutchison AL, Crowley V, France MW, Freemont AJ, et al. Bone loss in long-term renal transplantation: histopathology and densitometry analysis. Kidney Int 1999;55:2021-9.

5. Cvetkovic M, Mann GN, Romero DF, Liang XG, Ma Y, Jee WS, et al. The deleterious effects of long-term cyclosporin A, cyclosporin G, and FK506 on bone mineral metabolism in vivo. Transplant 1994;57:1231-7. 
Duarte PM, Nogueira Filho GR, Sallum EA, Sallum AW, Nociti Júnior FH. Short-term immunosuppressive therapy does not affect the density of the pre-existing bone around titanium implants placed in rabbits. Pesqui Odontol Bras 2003;17(4):362-6.

6. Del Pozo E, Lippuner K, Ruch W, Casez JP, Payne T, MacKenzie A, et al. Different effects of cyclosporin A on bone remodeling in young and adult rats. Bone 1995;16:271S-5S.

7. Donath K, Breuner GA. A method for the study of undecalcified bones and teeth with attached soft tissue. J Oral Pathol 1992;11:318-26.

8. Duarte PM, Nogueira Filho GR, Sallum EA, Toledo S, Sallum AW, Nociti Jr FH. The effect of an immunosuppressive therapy and its withdrawal on bone healing around titanium implants. A histometric study in rabbits. J Periodontol 2001;72:1391-7.

9. Duriez J, Flautre B, Blary MC, Hardouin P. Effects of the calcium channel blocker nifedipine on epiphyseal growth plate and bone turnover: a study in rabbit. Calcif Tissue Int 1993;52:120-4.

10. Esposito M, Hirsch JM, Lekholm U, Thomsen P. Biological factors contributing to failures of osseointegrated oral implants (II). Etiopathogenesis. Eur J Oral Sci 1998; 106:721-64.

11. Feehally J, Walls J, Mistry N, Horsburgh T, Taylor J, Veitch PS. Does nifedipine ameliorate cyclosporin A nephrotoxicity? Br Med J 1987;295:310.

12. Fischer RJ, Klinge B. Clinical and histological evaluation of ligature-induced periodontal breakdown in domestic ferrets immunosuppressed by cyclosporin-A. J Clin Periodontol 1994;21:240-9.

13. Fu E, Hsieh YD, Nieh S, Wikesjo UM, Liu D. Effects of cyclosporin-A on bone: an experimental study in the rat. J Periodontol 1999;70:189-94.

14. Fu E, Hsieh YD, Shen EC, Nieh S, Mao TK, Chiang CY. Cyclosporin-induced gingival overgrowth at the newly formed edentulous ridge in rats: a morphological and histometric evaluation. J Periodontol 2001;72:889-94.

15. Guo C-Y, Johnson A, Locke TJ, Eastell R. Mechanisms of bone loss after cardiac transplantation. Bone 1998; 22:267-71.

16. Jowell PS, Epstein S, Fallon MD, Reinhardt TA, Ismail F. 1,25-dihydroxyvitamin D3 modulates glucocorticoid-induced alteration in serum bone Gla protein and bone histomorphometry. Endocrinology 1987;120:531-6.

17. Kahan BD. Cyclosporin. N Engl J Med 1989; 32 1:1725-38.

18. Kapitan-Malinowska B, Talalaj M, Marcinowska-Suchowierska $\mathrm{E}$. The influence of calcium channels blockers on $\mathrm{Ca}-\mathrm{P}-\mathrm{Mg}$ homeostasis and bone mass in patients with cor- onary heart disease and hypertension. Osteoporos Int 1996;6(Suppl 1):184.

19. Kawana K, Takahashi M, Kushida K, Hoshino H, Sakata S, Inoue $\mathrm{T}$. The effect of cyclosporin A administration on bone metabolism in the rat evaluated by biochemical markers. $\mathrm{J}$ Endocrinol Invest 1996;19:499-504.

20. Keown PA, Stiller CR. Cyclosporine: a doubled-edged sword. Hosp Pract 1987;22:207.

21. Klein L, Lemel MS, Wolfe MS, Shaffer J. Cyclosporin A does not affect the absolute rate of cortical bone resorption at the organ level in the growing rat. Calcif Tissue Int 1994;55:295-301.

22. Lafferty KJ, Boel JF, Hodgkin P. Cyclosporin A (CsA): models for mechanism of action. Transplant Pro (Suppl) 1983; 15:2230-41.

23. Li XQ, Stenvenson S, Klein L, Davy DT, Shaffer JW, Goldberg VM. Differential patterns of incorporation and remodeling among various types of bone grafts. Acta Anat 1991;140:236-40.

24. Lindquist LW, Carlsson GE. Long terms effects on chewing with mandibular fixed prostheses on osseointegrated implants. Acta Odontol Scand 1985;43:39-45.

25. Miller LW, Pennington DG, McBride LR. Long-term effect of cyclosporine in cardiac transplantation. Transplant Proc 1990; 22:15-20.

26. Movsowitz C, Epstein S, Fallon M, Ohno K, Michi K, Yamaguchi A. Cyclosporin A in vivo produces severe osteopenia in rats: effect of dose and duration of administration. Endocrinol 1988;123:2571-7.

27. Orcel P, Denne MA, De Vernejoul MC. Cyclosporin-A in vitro decreases bone resorption, osteoclast formation, and the fusion of cells of the monocyte-macrophage lineage. Endocrinol 1991;128:1638-46.

28. Redlich K, Pietschmann P, Stulc T, Peterlik M. Comparative study on the effect of calcium channel blockers on basal and parathyroid hormone-induced bone resorption in vitro. Pharmacol Toxicol 1997;80:262-5.

29. Ritchie CK, Maercklein PB, Fitzpatrick LA. Direct effect of calcium channel antagonists on osteoclast function: alterations in bone resorption and intracellular calcium concentrations. Endocrinology 1994;135:996-1003.

30. Seymour RA, Heasman PA. Drugs, disease and the periodontium. Oxford: Oxford University Press; 1992. p. 80-91. 